\title{
TRANSFER OF UNDERTAKINGS LAW: BACK TO CONFUSION
}

\section{Paul Buggy, Head of Legal Services, Northern Ireland Housing Executive}

The transfer of undertakings legislation can potentially apply, in some circumstances, in the context of a contract for services: ${ }^{1}$ there is no doubt about the correctness of that proposition. But in what circumstances is the legislation likely to actually apply to such a contract? That question has been clearly answered by the European Court of Justice in its judgment in Suzen. ${ }^{2}$ It has also been clearly answered by the English Court of Appeal in its decision in ECM (Vehicle Delivery) Service v Cox. ${ }^{3}$ The problem is that the two answers are incompatible.

However, the differences between the two decisions should not be exaggerated. Both decisions are consistent with the proposition that the legislation can apply if any one or more of the following conditions is satisfied:

- If there is a transfer, to the transferee, of significant tangible assets.

- If there is a transfer of significant intangible assets (such as "knowhow").

- If the transferee takes over a major part of the transferor's workforce. ${ }^{4}$

But what if none of those conditions exists? Can the legislation apply even if there is no transfer of assets or of staff? Or, to put the question another way, can the legislation apply merely because the transferee carries out the same activities, for the same customer, as those which the transferor had carried out? Suzen is clear authority, at European level, against that proposition. However, in Cox, the Court of Appeal held that it is open to an employment tribunal to hold that the legislation does apply, even in the absence of a transfer of assets or of staff.

\section{The basic principles}

It will be necessary to look at the Cox judgment in greater detail, and to consider the legislation from a policy point of view. However, before doing so, it is important to refer to the basic principles of this area of law.

The legislation consists of the EEC Acquired Rights Directive 1977 and the implementing regulations, the Transfer of Undertakings (Protection of Employment) Regulations $1981^{5}$ ("TUPE"); the Regulations apply throughout the United Kingdom. In practice, in deciding whether the

${ }^{1}$ Rask and Christensen v ISS Kantineservice A/S [1993] IRLR 133, ECJ.

2 Suzen v Zehnacker Gebäudereinigung Gmbh Krankenhausservice [1997] IRLR 255, ECJ.

3 [1999] IRLR 559, CA.

4 See Suzen at p 259, para 24.

5 SI 1981/1794. 
Regulations apply in a particular situation, the task of British courts and tribunals is limited to determining whether the situation falls within the scope of the Directive; the requirements of the Directive must of course be ascertained in the light of the case-law of the European Court. ${ }^{6}$

Article 1(1) of the Directive defines the scope of the legislation, by providing that it cannot apply unless there is:

“. . . a transfer of an undertaking, business or part of a business ...".

Accordingly, the legislation cannot apply unless there is a transfer of an economic entity. In its case-law, the European Court of Justice consistently uses the term "economic entity" as a common denominator for describing an "undertaking", a "business", or a "part of a business" within the meaning of the Directive ${ }^{7}$. As Burton J pointed out in Whitewater Leisure Management Limited v Barnes, ${ }^{8}$ the transfer of an entity involves two separate requirements:

- $\quad$ There must be an entity. (This is a subject-matter requirement). ${ }^{9}$

- That entity must be the subject of a transfer. (This requirement relates to process).

The subject-matter (or "entity") requirement must be satisfied both in relation to the transferor and in relation to the transferee: As a result of the transfer, the alleged transferor must have ceased to be in charge of running an entity, ${ }^{10}$ and the alleged transferee must have begun to be in charge of running an entity. The point of the process (or "transfer") requirement is that the entity which ceases to be under the control of the transferor, and the entity which comes under the control of the transferee, must be one and the same. ${ }^{11}$

Therefore, the concept of a transfer of an entity involves three separate but inter-linked requirements:

- A transferor's entity requirement.

- A transferee's entity requirement.

- The transfer requirement.

If the European and British case-law is analysed in terms of those three requirements, many of its apparent contradictions disappear.

6 See Betts v Brintel Helicopters Ltd and KLM ERA Helicopters (UK) Ltd [1997] IRLR 361, CA, at p 366, para 50.

7 See the Opinion of Advocate General Van Gerven in Schmidt v Spar - und Leihkasse der fruheren Amter Bordesholm, Kiel und Cronshagen [1994] IRLR 302, ECJ, at p 306, para 13.

8 [2000] IRLR 456, EAT, at p 457, para 6.

9 See Allen v Amalgamated Construction Co. Ltd [2000] IRLR 119, ECJ, at p 134, para 24.

10 The employees lost in Betts primarily because the Court of Appeal concluded that the entity requirement was not satisfied in relation to the transferor. See Betts, at p 366, para 45.

11 See Spijkers v Gebroeders Benedik Abbatoir BV [1986] ECR 1119, ECJ, at paras 10 and 11 of the judgment. 


\section{What is an "entity"?}

The term "entity" was first defined by the European Court in 1997, in its judgment in Suzen; that definition has been endorsed and re-affirmed by the Court in subsequent cases. ${ }^{12}$ According to the Suzen judgment:

"The term entity ... refers to an organised grouping of persons and assets facilitating the exercise of an economic activity which pursues a specific objective". ${ }^{13}$

Later in the same judgment, ${ }^{14}$ the Court warned:

"An entity cannot be reduced to the activity entrusted to it. Its identity also emerges from other factors, such as its workforce, its management staff, the way in which its work is organised, its operating methods or indeed, where appropriate, the operational resources available to it".

Subsequent European case-law indicates that the Suzen definition is valid in all types of contracting-out situations. ${ }^{15}$

\section{What is the "transfer" requirement?}

In Spijkers v Gebroeders Benedik Abbatoir $C V,{ }^{16}$ there was no doubt that, as a result of the alleged transfer, the alleged transferor had ceased to be in charge of an entity, and that, by the same process, all the necessary constituent elements for an entity had come into the hands of the alleged transferee. Accordingly, Spijkers is a case which is concerned only with the concept of a transfer (as distinct from the concept of an entity). The European Court's 1986 judgment in that case continues to be the leading authority on the question of what conditions have to be satisfied in order to comply with the process (or "transfer") requirement.

According to the Spijkers judgment, in deciding whether a transferor's entity has been the subject of a "transfer", the key question is whether the entity: "was disposed of as a going concern, as would be indicated, inter alia, by the fact that its operation was actually continued or resumed by the [alleged transferee], with the same or similar activities". ${ }^{17}$ And the Court points out elsewhere in the judgment that: “. . . the decisive criterion for establishing whether there is a transfer for the purposes of the directive is whether the [entity] in question retains its identity". ${ }^{18}$

Therefore, Spijkers shows that the transfer requirement can be satisfied in relation to a contract if, both before and after the making of that contract, much the same activities are carried out for the same customer.

12 See Francisco Hernández Vidal SA v Gomez Perez [1999] IRLR 132, ECJ; Sanchez. Hidalgo v Asociacion de Servicios Aser and Sociedad Cooperativa Minerva [1999] IRLR 136, ECJ; and Allen.

13 Suzen, at p 259, para 13.

14 At para 15 of the judgment.

15 See the cases cited at $\mathrm{n} 12$ above.

16 See $n 11$ above.

17 Para 12 of the judgment.

18 Para 11 of the judgment. 


\section{The Cox decision}

In Cox, the relevant workers had been employed by the transferor for the purposes of carrying out a vehicle delivery contract with the transferor's customer, VAG. The transferor lost that contract, which was then awarded to ECM (the alleged transferee). There was no transfer of material assets, and no significant transfer of intangible assets. ECM took on none of the transferor's staff. Nevertheless, the industrial tribunal held that the Transfer of Undertakings Regulations applied in the circumstances. According to the industrial tribunal's decision, the relevant economic entity was: “. . . the VAG contract itself and the activities which surrounded that VAG contract." 19

The Court of Appeal's reasons for upholding the employment tribunal decision emerge from the judgment of Mummery LJ. He justified the upholding of the tribunal's decision mainly on the basis of three propositions: ${ }^{20}$

- The Spijkers line of authority ${ }^{21}$ (with its emphasis upon an examination of the similarities between activities before and after the transfer) continued to be good law.

- Spijkers showed that the "necessary factual appraisal" was a matter for the adjudicating authority at first instance (in this situation, the employment tribunal).

- The Suzen judgment had to be read within the context of the particular factual circumstances of the Suzen case.

However, none of those propositions provides convincing support for the Court of Appeal's decision. First, as has been emphasised above, the Spijkers principle is concerned only with the "transfer" requirement; it provides no support for the proposition that activities can equate to an entity. Secondly, although the question of whether the legislation applies, in a particular scenario, is a question of fact, the court or tribunal at first instance must find those facts within the constraints of the legal principles established by European case-law. Thirdly, post-Suzen European case-law clearly shows that the Suzen definition of an entity is applicable in all sorts of contractingout situations.

\section{The policy issue}

In the United Kingdom, the Suzen judgment has been the subject of much criticism from a policy perspective. Cox is, at least in part, a response to that criticism. The main argument of the critics is that the Suzen ruling defeats the purpose of the legislation, by allowing employers to evade the

Cox (n 3 above) at p 560, para 13.

20 See Cox at pp 561 and 562 (para 23 of Mummery LJ's judgment).

21 That line of authority includes the case of Schmidt [1994] IRLR 302, ECJ. In Schmidt, the Court proceeded on the basis of an assumption that the relevant transfer's subject-matter was an entity, but did not decide the point; see Ledernes Hovendorganisation (acting for Rygaard) v Dansk Arbejdsgiverforening (acting for Stro Molle Akustik A/S)[1996] IRLR 51, ECJ, at p 56, para 20. 
applicability of the legislation (by the simple expedient of declining to take on any of the transferor's staff). ${ }^{22}$

However, this argument is misconceived. Contrary to the view of the critics, the legislation does not exist in order to safeguard employee's rights in all circumstances. Its employee-protection aim is much more narrowly focused; as the title of the legislation itself shows, the Directive is aimed at safeguarding employee's rights if, and only if, there is a transfer of an entity. ${ }^{23}$ Furthermore, there is nothing illogical in deciding that, in some situations, the Directive will apply if transferor's employees are taken on, and will not apply if they are not taken on; in such situations, the employees themselves may be the sole or main element of the entity. As the European Court pointed out in Francisco Hernandez Vidal: “. . . an organised grouping of wage earners who are specifically and permanently assigned to a common task may, in the absence of other factors of production, amount to an economic entity". ${ }^{24}$

\section{CONCLUSION}

We have been in this situation before. During the mid-1990s, there was considerable confusion as to the precise circumstances in which TUPE was likely to actually apply, in the context of contracts for services. During that period, the confusion was caused by the maddeningly vague manner in which the European Court of Justice sometimes chooses to express itself. But, in Suzen, the Court clarified its position. Now, there is confusion once again, on the same issue as before. This time, however, the source of the problem is closer to home.

22 See para 29 of the judgment of Lindsay P in RCO Support Services and Aintree Hospital Trust v Unison [2000] IRLR 264, EAT, at p 629. For a particularly trenchant commentary, see "Highlights" in the June 1997 edition of the Industrial Relations Law Reports.

23 According to its title, the legislation is a directive "on the approximation of the laws of the Member States relating to the safeguarding of employees' rights in the event of transfers of undertakings, businesses or parts of businesses".

24 Francisco Hernández Vidal, at p 134, para 27. 